\title{
Studija primarnoga otvaranja šuma gospodarske jedinice Crno jezero - Marković rudine Šumarije Otočac
}

\author{
Ivica Papa, Tibor Pentek, David Janeš, Enio Valinčić, Andreja Đuka
}

\begin{abstract}
Nacrtak - Abstract
Kvalitetno isplanirana $i$ u šumski ekosustav optimalno uklopljena šumska prometna infrastruktura jedan je od osnovnih preduvjeta potrebnih za današnje racionalno gospodarenje šumskim ekosustavom. Ukupna količina šumskih prometnica, njihov razmještaj u prostoru te njihove propisane tehničke značajke moraju biti dostatne za što kvalitetnije upravljanje šumom. Ako je šumska prometna infrastruktura pravilno položena u prostoru, ona omogućuje izvođenje svih zadataka predviđenih šumskogospodarskim planovima na određenom šumskom području, uz minimalne troškove njihove izgradnje i održavanja uz maksimalan učinak. U ovom radu prikazano je sadašnje stanje primarne otvorenosti gospodarske jedinice Crno jezero - Marković rudine te su predložene smjernice njezina daljnjega otvaranja s ciljem dostizanja vrlo dobre primarne relativne otvorenosti. Terenski su podaci obrađeni u računalnim programima ArcGIS 10.4 i QGIS 2.18.20. Ustanovljeno je da klasična otvorenost šuma u toj gospodarskoj jedinici iznosi 13,66 km/1000 ha, što ne udovoljava ni minimalno propisanoj klasičnoj otvorenosti koja za gorsko-planinsko reljefno područje iznosi $15 \mathrm{~km} / 1000$ ha. Analizirajući rezultate primarne relativne otvorenosti, zatečeno je vrlo slično stanje kao $i$ kod klasične otvorenosti: primarna relativna otvorenost iznosi $45,05 \%$, što se smatra nedovolinom primarnom relationom otvorenošću. Nadalje, analizirana je postojeća srednja geometrijska udaljenost privlačenja drva za svaki odsjek zasebno te je utorđeno da taj parametar na razini gospodarske jedinice iznosi 258,74 m. Pomnim planiranjem projektirano je ukupno 53,05 km novih trasa šumskih cesta, što je u konačnici rezultiralo povećanjem klasične otvorenosti šuma na 22,82 km/1000 ha, primarne relativne otvorenosti na 75,8\% te smanjenjem srednje geometrijske udaljenosti privlačenja drva na $140,55 \mathrm{~m}$.
\end{abstract}

Ključne riječi: šumske ceste, relativna otvorenost šuma, geometrijska udaljenost privlačenja drva, ArcGIS

\section{Uvod - Introduction}

\subsection{Uloga šumskih cesta - The role of forest roads}

Iako šumske ceste ispunjavaju i ostale višestruke funkcije (Jeličić 1983, Šikić i dr. 1989, Enache 2009), Potočnik (1996) navodi kako se njihova uloga u omogućavanju aktivnosti vezanih uz gospodarenje šumama ipak smatra najznačajnijom. Danas $\mathrm{su}, \mathrm{u}$ suvremenom šumarstvu, svi radovi vezani uz gospodarenje šumama, kao i njihovo korištenje $\mathrm{u}$ različite svrhe, nezamislivi bez šumske prometne infrastrukture. Postizanje ciljeva potrajnoga gospo- darenja, među ostalim, omogućeno je i izgradnjom unaprijed planirane mreže šumskih cesta, kojom se uvelike povećava učinkovitost radova pri gospodarenju uz olakšano korištenje općekorisnih funkcija šuma.

Sever (1992) navodi kako su u hrvatsko šumarstvo u razdoblju od 1960. do 1970. godine uvedeni strojevi u sječu, izradbu i transport drva te u poslove vezane uz uzgajanje šuma. Posljedično dolazi do nagloga porasta proizvodnosti zahvaljujući mehaniziranju šumskih radova, što autor stavlja u izravnu vezu s intenzivnijom izgradnjom šumske prometne infrastrukture koja je omogućila primjenu strojeva. 
U svojim istraživanjima Stampfer (2010) također ističe kako se učinkovitost pojedinoga sustava pridobivanja drva temelji na postojećoj mreži šumskih prometnica.

Jeličić (1988) naglašava značenje šumskih cesta za cjelokupno gospodarenje šumama, posebice za pridobivanje drva, jer u slučaju nepravodobnoga otvaranja šuma neujednačeno se raspoređuje obujam sječa po površini obrasloj šumom, što potvrđuje Krpan (1992) koji navodi da 3/4 prometa po učestalosti pripada prometu izvan radova pridobivanja drva, dok se po opterećenju taj odnos mijenja, jer prijevoz drva opterećuje šumske ceste sa $67 \%$. Stoga je sastavni dio planiranja u šumarstvu i otvaranje šuma mrežom šumskih cesta, čime šume postaju dostupne gospodarenju, odnosno provođenju svih zadataka određenih planovima gospodarenja (Pentek i dr. 2005).

Šumske su ceste veoma važne za gospodarenja šumama. Brojni ulasci u šumu, koji su posljedica radova u gospodarenju, iziskuju izgradnju i održavanje prikladnih šumskih cesta. Primjena gotovo svih sustava pridobivanja drva zahtijeva izgradnju šumskih cesta određene gustoće i prostornoga rasporeda. One su veoma važne pri sprečavanju širenja šumskih požara jer omogućuju osmatranje i pravodobnu dojavu opasnosti, dopremu opreme za gašenje, a ujedno su i prepreke širenju vatre i nastanku biološki uzrokovanih šumskih šteta (Tehrani i dr. 2015).

\subsection{Planiranje šumskih prometnica - Planning of forest roads}

Planiranje je prva i najvažnija faza uspostave optimalne mreže šumskih prometnica na terenu, što je krajnji cilj otvaranja šuma. Optimalna mreža šumskih cesta jamči racionalnije i potpunije, a svakako i uspješnije gospodarenje čitavim šumskim ekosustavom, uz minimalno narušavanje ekoloških zakonitosti i ekološke ravnoteže koja tu vlada (Pentek 2002).

Dean (1997) smatra da je s obzirom na važnost (udio) troškova izgradnje i održavanja šumskih cesta prijeko potrebno isplanirati najučinkovitiju te što jeftiniju mrežu primarnih šumskih prometnica, dok Murray (1998) ističe da je planiranje šumske cestovne mreže radi učinkovitijega pridobivanja drva težak i dugotrajan posao.

Tijekom planiranja pristupa se analizi postojeće mreže šumskih prometnica kako bi se utvrdila njezina kakvoća, količina i mogući nedostaci te na temelju dobivenih rezultata odredila potreba za daljnjim otvaranjem nekoga šumskoga područja radi postizanja optimalnoga rasporeda šumskih prometnica.

Prema Penteku i dr. (2014) planiranje se šumskih prometnica, prema razini na kojoj se planiranje provodi, prema složenosti (općenitosti ili detaljnosti) postupka planiranja, sukladno razdoblju za koje se planiranje provodi te s obzirom na veličinu područja na koje se planiranje odnosi, može razdijeliti u tri razine:

$\Rightarrow$ planiranje primarnoga i sekundarnoga otvaranja šuma na razini države odnosno reljefnoga područja (nizinsko, brdsko, planinsko, krško). U reljefna se područja objedinjuju gospodarske jedinice sličnih sastojinskih i stanišnih značajki. Najviša je razina planiranja razina od koje se započinje tzv. globalno odnosno strategijsko planiranje.

$\Rightarrow$ planiranje šumske transportne infrastrukture (i primarnih i sekundarnih šumskih prometnica $u$ okviru tzv. sveobuhvatnoga planiranja) na razini gospodarske jedinice srednja je razina planiranja, opće planiranje - taktičko planiranje

$\Rightarrow$ planiranje konkretne šumske prometnice (primarne ili sekundarne) - rezultati općega (taktičkoga) planiranja na razini pojedine gospodarske jedinice usmjeravaju nas ka planiranju na najnižoj razini (lokalno planiranje - operativno planiranje), nakon kojega slijedi faza projektiranja šumskih prometnica.

\section{Materijal i metode-Material and methods}

\subsection{Mjesto istraživanja - Research area}

Jedinica je smještena na obroncima sjevernoga Velebita te ga na svojem jugozapadnom dijelu povezuje s Ličkim sredogorjem i Malom Kapelom, a svojom istočnom stranom omeđuje je Gacko polje. Karakterizira je znatan visinski raspon - najniža je točka $449 \mathrm{~m} \mathrm{n}$. v. (odsjek 3e), a najviši je vrh na 1105 $\mathrm{m}$ n. v. u Marković rudinama.

Istraživana gospodarska jedinica površine je 5345,17 ha, podijeljena u 123 odjela odnosno 253 odsjeka. Od ukupne površine gospodarske jedinice na obraslo šumsko zemljište otpada $98,22 \%$ površine (5250,20 ha), na neobraslo šumsko zemljište 1,14 \% površine (66,93 ha), dok se neplodno šumsko zemljište rasprostire na $0,63 \%$ površine $(33,84 \mathrm{ha})$. Drvna zaliha gospodarske jedinice iznosi $1195763 \mathrm{~m}^{3}(228$ $\mathrm{m}^{3} / \mathrm{ha}$ ), od čega su tri najzastupljenije vrste drveća: obična jela $706620 \mathrm{~m}^{3}$ (59,09 \% drvne zalihe), obična 
bukva $273683 \mathrm{~m}^{3}(22,89 \%$ drvne zalihe) i gorski javor $105061 \mathrm{~m}^{3}$ (8,79\% drvne zalihe).

U gospodarskoj jedinici prevladava preborni način gospodarenja, tj. preborne sastojine koje dolaze na $82,5 \%$ obrasle površine gospodarske jedinice, raznodobne sastojine dolaze na $16 \%$ obrasle površine gospodarske jedinice, dok regularne sastojine u gospodarskoj jedinici dolaze na 76,58 ha, odnosno na $1,5 \%$ obrasle površine gospodarske jedinice.

Prema namjeni šuma i šumskih zemljišta koja se nalaze u sklopu ove gospodarske jedinice najveći dio površine od 4422,13 ha pripada gospodarskim šumama, a manjim dijelom od 724,16 ha zaštitnim šumama, dok se u toku rijeke Gacke nalazi Zaštićeni krajobraz »Gacko polje« koji svojim obuhvatom zahvaća rubne dijelove odjela/odsjeka 55a, $60 \mathrm{~b}, 85 \mathrm{c}, 122 \mathrm{c}$ i 123a ove gospodarske jedince i koji zauzima 3,43 ha, zbog čega su ti odsjeci svrstani $\mathrm{u}$ kategoriju šume s posebnom namjenom (Anon. 2017).
Gospodarska podjela gospodarske jedinice Crno jezero - Marković rudine prikazana je na slici 1.

\subsection{Klasična otvorenost šuma - Classical forest openness}

Primarna klasična otvorenost šuma daje samo orijentacijski podatak o količini svih sastavnica primarne šumske prometne infrastrukture na određenoj šumskoj površini, ali ne i o njihovu prostornom razmještaju. Klasična se otvorenost šuma uvijek mora iskazivati u kombinaciji sa srednjom udaljenosti privlačenja drva (Pentek 2012), a izražava su u m/ ha ili km/1000 ha. Bumber (2011) navodi kako je uobičajeno gustoću šumskih cesta iskazivati na razini gospodarske jedinice koja je zaokružena šumska površina, sličnih orografskih (reljefnih) i sastojinskih značajki te načina gospodarenja šumom. Hodić i Jurušić (2011) definiraju minimalnu te planiranu otvorenost za 2020. godinu po reljefnim područjima (tablica 1).

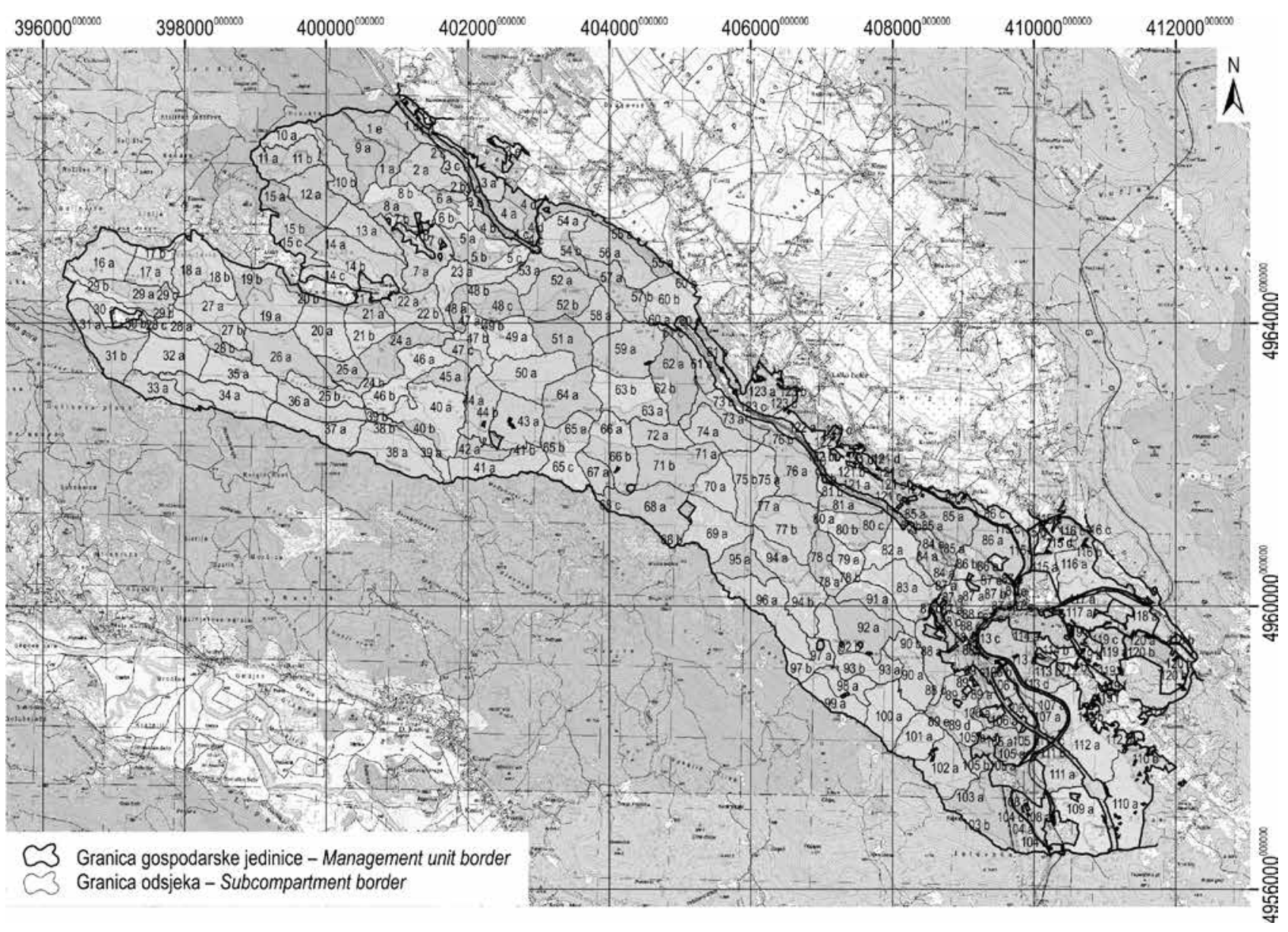

Slika 1. Gospodarska jedinica Crno jezero - Marković rudine

Fig. 1 Management Unit Crno jezero - Marković rudine 
Tablica 1. Minimalna klasična i planirana otvorenost za 2020. po reljefnim područjima

Table 1 Minimum primary road density and planned primary road density by 2020 according to relief areas

\begin{tabular}{|l|c|c|}
\hline \multicolumn{1}{|c|}{ Reljefno područje - Relief area } & $\begin{array}{c}\text { Minimalna } \\
\text { klasična } \\
\text { otvorenost } \\
\text { Minimal classical } \\
\text { openness }\end{array}$ & $\begin{array}{c}\text { Planirana } \\
\text { (ciljana) klasična } \\
\text { otvorenost 2020. } \\
\text { Planned classical } \\
\text { openness 2020 }\end{array}$ \\
\hline Nizinsko područje - Lowland area & 10 & 13,00 \\
\hline $\begin{array}{l}\text { Prigorsko-brdsko područje } \\
\text { Hilly area }\end{array}$ & $13,00-15,00$ & 20,00 \\
\hline $\begin{array}{l}\text { Planinsko područje } \\
\text { Mountainous area }\end{array}$ & 20,00 & 25,00 \\
\hline Krško područje - Karst area & - & 15,00 \\
\hline
\end{tabular}

\subsection{Relativna otvorenost šuma - Relative forest openness}

Relativna otvorenost (Pentek 2002), za razliku od klasične otvorenosti, daje dobar uvid u stvarnu učinkovitost mreže šumskih prometnica. Ona prikazuje postotni udio otvorene površine $u$ odnosu na ukupnu površinu analiziranih gospodarskih jedinica. Također pruža dobar pregled prostornoga rasporeda šumskih prometnica, daje mogućnost utvrđivanja otvorenih i neotvorenih površina $i$ projektantu nudi mogućnost odabira najpovoljnijih inačica budućih šumskih prometnica. Relativna se otvorenost računa metodom omeđenih površina koje su na određenoj udaljenosti s obje strane i paralelno s trasom šumske prometnice. Pojam omeđenih površina (engl. buffer) prvi je u šumarstvo uveo Backmund (1966) za računanje koeficijenta otvorenosti.

Ovisno o kategoriji šumske prometnice za koju se ocjenjuje relativna otvorenost, ona može biti:

$\Rightarrow$ primarna relativna otvorenost (otvorenost primarnim šumskim prometnicama)

$\Rightarrow$ sekundarna relativna otvorenost (otvorenost sekundarnim šumskim prometnicama).

Udaljenost od ruba omeđene površine do ceste dvostruka je vrijednost ciljane srednje udaljenosti privlačenja drva. Izračun primarne relativne otvorenosti predstavlja odnos između otvorene i ukupne površine određenoga šumskoga područja, s tim da se u obzir uzima samo primarna šumska prometna infrastruktura (izraz 1).

$O_{\mathrm{R}(\mathrm{P})}=\frac{P_{\mathrm{O}(\mathrm{P})}}{P_{\mathrm{U}}} \times 100, \%$ gdje je:

$O_{\mathrm{R}(\mathrm{P})}$ primarna relativna otvorenost, $\%$

$P_{\mathrm{O}(\mathrm{P})}$ otvorena površina za izračunatu prosječnu ciljanu stvarnu srednju udaljenost privlačenja drva, ha

$P_{\mathrm{U}} \quad$ ukupna površina otvaranoga područja, ha.

Primarna se relativna otvorenost na temelju udjela dostupne šumske površine za definiranu ciljanu geometrijsku udaljenosti privlačenja drva pripadajuće kategorije reljefnoga područja Pravilnikom o provedbi mjere M04 »Ulaganja u fizičku imovinu«, podmjere 4.3. »Potpora za ulaganja $\mathrm{u}$ infrastrukturu vezano uz razvoj, modernizaciju i prilagodbu poljoprivrede i šumarstva«, tipa operacije 4.3.3. »Ulaganje $u$ šumsku infrastrukturu « iz Programa ruralnoga razvoja Republike Hrvatske za razdoblje 2014.-2020. (NN 106/15, 65/17, 77/17) (dalje: Pravilnik), procjenjuje kako slijedi: $\Rightarrow$ nedovoljna (dostupno $<55 \%$ šumske površine) $\Rightarrow$ slaba (dostupno od 55 do $65 \%$ šumske površine) $\Rightarrow$ dobra (dostupno od 65 do $75 \%$ šumske površine) $\Rightarrow$ jako dobra (dostupno od 75 do $85 \%$ šumske površine)

$\Rightarrow$ izvrsna (dostupno $>85 \%$ šumske površine).

Dodatno, primarna relativna otvorenost $\mathrm{u}$ kombinaciji s koeficijentom učinkovitosti postojeće mreže primarne šumske prometne infrastrukture koristi se za podrobniju analizu kakvoće prostornoga rasporeda odnosno učinkovitosti postojeće mreže primarne šumske prometne infrastrukture ili njezine pojedine sastavnice. Koeficijentom učinkovitosti postojeće mreže primarne šumske prometne infrastrukture izračunava se prema (izraz 2):

$k_{\mathrm{U}}=\left(1-\frac{P_{\mathrm{N}}}{P_{\mathrm{U}}}\right) \times 100$

gdje je:

$k_{\mathrm{U}}$ koeficijent učinkovitosti pojedine šumske ceste $P_{\mathrm{N}}$ površina neučinkovitih omeđenih površina, ha $P_{\mathrm{U}}$ površina ukupno omeđenih površina, ha.

Kako su, s jedne strane, upravo šumske ceste jedno od najvećih ulaganja u šumarstvu općenito (Bosner i dr. 2012), odnosno najveća stavka u ukupnim troškovima proizvodnje drvnih sortimenata (Pearce 1974), a s druge strane omogućuju nesmetano i učinkovito izvođenje svih radnih zahvata iz šumskogospodarskih planova, važno je da upravo planiranje šumskih cesta bude izvedeno na krajnje profesionalan način uzimajući u obzir ekonomske, tehničko-tehnološke, okolišno-ekološke te sociološko-estetske kriterije. 


\subsection{Srednja udaljenost privlačenja - Average timber extraction distance}

Srednja je udaljenost privlačenja drva parametar koji na određenoj šumskoj površini (odjelu, odsje$\mathrm{ku}$, sječini) opisuje prosječnu udaljenost na kojoj se privlači drvo, tj. udaljenost od mjesta sječe stabla (panja) do mjesta skupljanja drva (pomoćno stovarište, šumska cesta). Ovisno o prostornom rasporedu linija privlačenja drva, razlikuju se središnje i usporedno privlačenje. Središnjim se privlačenjem smatra privlačenje drva od svake točke (panja) na šumskoj površini do jednoga središta (pomoćnoga stovarišta), dok se usporednim smatra privlačenje u usporednim pravcima na šumsku cestu.

Određivanje srednje udaljenosti privlačenja drva bilo je, a zasigurno će i biti područje velikoga interesa mnogih domaćih i stranih stručnjaka u budućim istraživanjima. Tako Dietz i dr. (1984), prema prijašnjim istraživanjima Segebadena (1964), Backmunda (1966) i Abegga (1978), dijele srednju udaljenost privlačenja drva u tri glavne skupine:

$\Rightarrow$ teorijska srednja udaljenost privlačenja drva izračunava se iz teorijskoga modela mreže šumskih cesta odnosno iz teorijskoga razmaka između šumskih cesta

$\Rightarrow$ geometrijska srednja udaljenost privlačenja drva - udaljenost od čvorišta mreže pravilnih četverokuta do stvarno ucrtane najbliže šumske ceste

$\Rightarrow$ stvarna srednja udaljenost privlačenja drva udaljenost od čvorišta mreže pravilnih četverokuta do šumske ceste pravcem kojim se privlačenje stvarno i obavlja.

\subsection{Planiranje i projektiranje idejnih trasa šumskih cesta na karti - Planning of forest road concept design alingment on map}

Planiranje i projektiranje idejnih trasa šumskih cesta podijeljeno je $\mathrm{u}$ više prioritetnih razina ovisno po veličini područja za koje se novoplanirana mreža šumskih cesta izrađuje. Kako je u ovom radu razina planiranja bila vezana uz gospodarsku jedinicu, možemo zaključiti da se radilo o planiranju šumskih cesta na taktičkoj odnosno srednjoj razini planiranja iz razloga što se upravo na taktičkoj razini otvaraju neotvorena ili nedovoljno otvorena šumska područja te se unapređuje mreža primarne šumske prometne infrastrukture u cjelini (Pentek 2016).

Po završetku analize relativne otvorenosti šuma na razini gospodarske jedinice ustanovljene su i izlučene neotvorene površine za određenu prosječnu ciljanu stvarnu srednju udaljenost privlačenja
(200 m), odnosno one površine koje su pri raščlambi relativne otvorenosti ostale izvan omeđenih površina. Upravo su te površine unutar gospodarske jedinice bile moguća mjesta prolaska idejnih trasa budućih šumskih cesta i u daljnjem postupku iznalaženja optimalnih novoplaniranih trasa budućih šumskih cesta sva je pozornost bila usmjerena ka tim područjima. Tijekom procesa planiranja kao podloga korištena je Hrvatska osnovna karta (HOK), tj. osnovna službena državna karta izrađena u mjerilu $1: 5000$, ekvidistante $5 \mathrm{~m}$.

Početna točka idejnih trasa šumskih cesta pozicionirana je na pojedinoj sastavnici postojećega primarnoga transportnoga sustava, određene su kardinalne (ključne) i/ili krajnje točke koje je idejna trasa trebala spojiti te je na temelju njihove međusobne udaljenosti i visinske razlike izračunat nagib nul-linijskog poligona, za svaki segment idejne trase zasebno, prema izrazu 3:

$n=\frac{H}{L} \times 100$

gdje je:

$n$ nagib nul-linije, $\%$

$H$ visinska razlika između zadanih točaka, $\mathrm{m}$

$L$ udaljenost između zadanih točaka, $\mathrm{m}$.

Važno je napomenuti kako je kao granična, maksimalna vrijednost nagiba nul-linije definiran nagib u iznosu od $8 \%$. Na temelju izračunatoga nagiba svakoga segmenta nul-linije (dionice između točaka: početne i kardinalne, početne i krajnje, kardinalne i kardinalne i/ili kardinalne i krajnje) izračunavan je korak šestara, odnosno vrijednost koja predstavlja stalnu udaljenost između slojnica za određeni nagib, prema izrazu 4:

$$
d=\frac{e \times 100}{n}
$$

gdje je:

d udaljenost između slojnica, tzv. korak šestara, $\mathrm{m}$

$e$ visinska razlika između slojnica, tzv. ekvidistanta, $\mathrm{m}$

$n$ nagib nul-linije, $\%$.

Cilj je ovoga rada bio, na temelju kriterija određenih Pravilnikom, ustanoviti postojeću primarnu otvorenost gospodarske jedinice Crno jezero - Marković rudine te predložiti smjernice daljnjega otvaranja.

Određivanje srednje geometrijske udaljenosti privlačenja omogućeno je pomoću programa Arc- 
GIS, tj. pomoću alata Euclidean distance na razini pojedinoga odsjeka, dok su za grafički prikaz analize sjedinjene te prikazivane na razini gospodarske jedinice (slike 2 i 3 ).

Sve potrebne analize $\mathrm{u}$ radu vezane $\mathrm{uz}$ parametre otvorenosti istraživanoga područja odnosno gospodarske jedinice rađene su pomoću programskih paketa ArcGIS 10.4 i QGIS 2.18.20.

\section{Rezultati s raspravom - Results with discussion}

\subsection{Raščlamba postojeće mreže primarnih} šumskih prometnica - Analysis of the existing network of primary forest roads

\subsubsection{Postojeća klasična otvorenost - Existing classical forest openness}

$\mathrm{Na}$ području gospodarske jedinice Crno jezero - Marković rudine, koja se prostire na 5345,17 ha, nalazi se ukupno 103,06 km javnih i šumskih cesta. Kroz istraživanu gospodarsku jedinicu prolazi i autocesta A1 Zagreb - Split (slika 2) koja nije uzeta u obračun. Razlog isključivanja autoceste iz obračuna klasične otvorenosti i daljnih analiza leži u činjenici što je planiranje privlačenja drva na pomoćno stovarište koje se nalazi u cestovnom zemljištu i zaštitnom pojasu moguće za sve kategorije javnih cesta osim autocesta. Ta je odredba definirana Smjernicama za izradu Elaborata radilišta za radove u šumarstvu koje je donijela Hrvatska komora inženjera šumarstva i drvne tehnologije.

Od ukupne količine cesta u gospodarskoj jedinici:

$\Rightarrow 33,75 \mathrm{~km}$ čine javne ceste odnosno $32,75 \%$

$\Rightarrow 67,25 \mathrm{~km}$ čine šumske ceste odnosno $67,25 \%$.

Sukladno Pravilniku daljnjom analizom javnih odnosno šumskih cesta, tj. njihovih pojedinih dionica, a koje prolaze granicom gospodarske jedinice

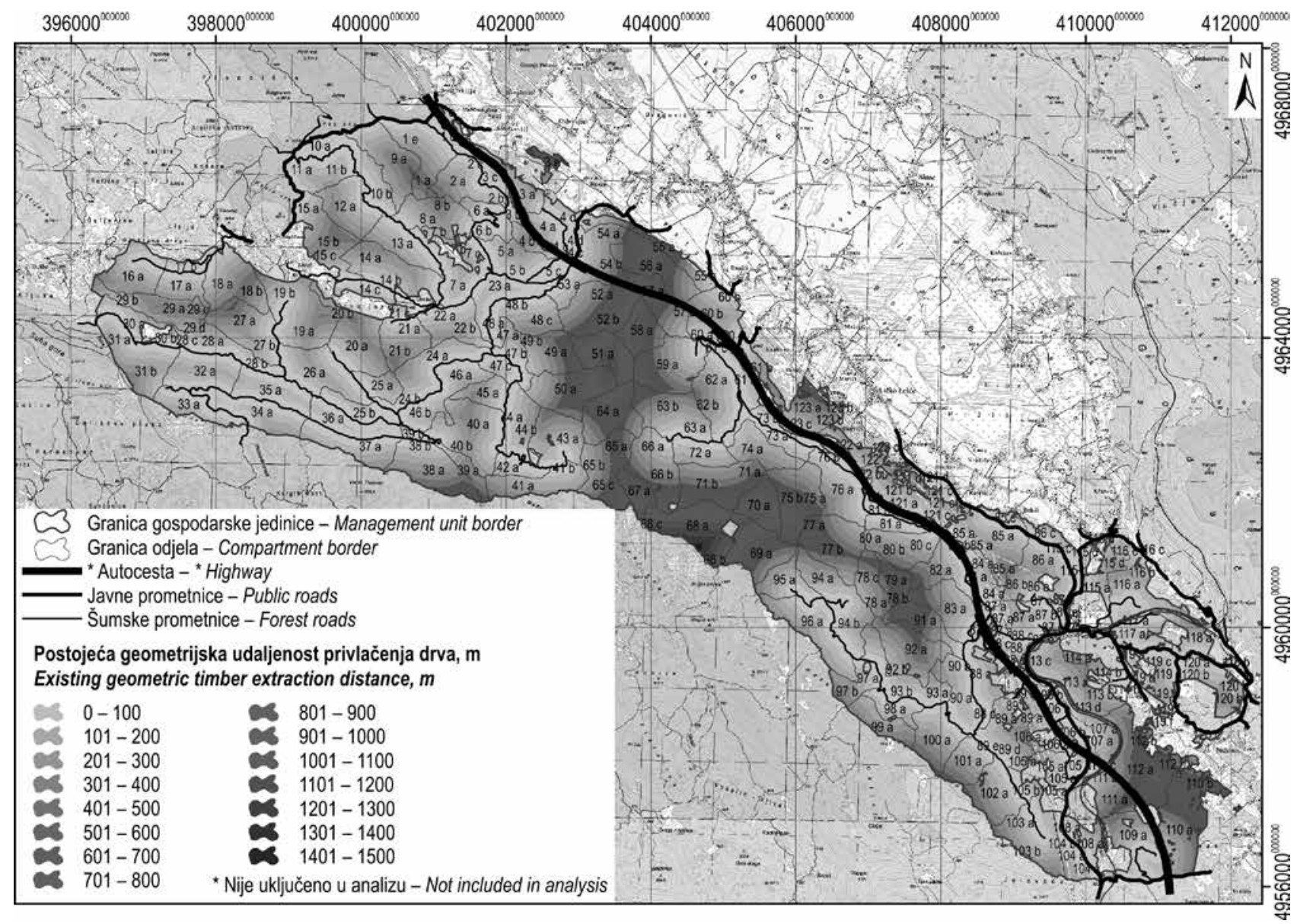

Slika 2. Postojeća mreža primarne prometne infrastrukture i geometrijska udaljenost privlačenja drva u gospodarskoj jedinici Crno jezero - Marković rudine

Fig. 2 Existing primary road infrastructure network and geometric timber extraction distance (Euclidean distance) in Management Unit Crno jezero - Marković rudine 
ili najviše do $250 \mathrm{~m}$ udaljenosti od granice s njezine vanjske ili najviše do $125 \mathrm{~m}$ udaljenosti od granice $\mathrm{s}$ njezine unutarnje strane, uzeta je u obračun gustoća primarne šumske prometne infrastrukture s polovicom njezine duljine (50\% duljine). Tako je dobivena konačna duljina cesta $(73,02 \mathrm{~km})$ koje ulaze $\mathrm{u}$ izračun otvorenosti i koje čine klasičnu otvorenost gospodarske jedinice u iznosu od 13,66 km/1000 ha, što ne udovoljava ni minimalno propisanoj klasičnoj otvorenosti koja prema Pravilniku za gorsko-planinsko reljefno područje iznosi $15 \mathrm{~km} / 1000$ ha.

\subsubsection{Postojeća relativna otvorenost - Existing primary relative accessibility}

Nakon izračuna klasične otvorenosti pristupilo se izradi analize relativne otvorenosti istraživanoga područja, koja je provedena metodom polaganja površina (engl. buffer). Oko sastavnica primarne transportne infrastrukture za širinu pojasa otvaranja korištena je vrijednost ciljane geometrijske udaljenosti privlačenja drva, koja prema Pravilniku za gorsko-planinsko reljefno područje iznosi $200 \mathrm{~m}$. Navedenom analizom došli smo do ovih spoznaja:

$\Rightarrow$ ukupno otvorena površina iznosila je 3450,35 ha

$\Rightarrow$ jednostruko otvorena površina (zone bez preklapanja) unutar gospodarske jedinice iznosila je 1398,92 ha

$\Rightarrow$ višestruko otvorena površina (zone preklapanja više omeđenih površina) unutar gospodarske jedinice iznosila je 1007,71 ha

$\Rightarrow$ neotvorena površina gospodarske jedinice iznosila je 2938,54 ha.

Zbrajanjem jednostruko i višestruko otvorenih površina $\mathrm{u}$ gospodarskoj jedinici te stavljanjem $\mathrm{u}$ postotni odnos s njezinom ukupnom površinom dobivena je postojeća primarna relativna otvorenost u iznosu od 45,02\%. Uspoređujući dobivenu vrijednost sa sustavom procjene primarne relativne otvorenosti šuma prikazan u poglavlju 2.3 vidljivo je kako se postojeća primarna relativna otvorenost gospodarske jedinice Crno jezero - Marković rudine svrstava u kategoriju nedovoljne primarne relativne otvorenosti.

Zbog visoke višestruko otvorene površine koja je $\mathrm{s}$ jedne strane neizbježna zbog pojavnosti raskrižja na šumskom transportnom sustavu te vrlo zahtjevne orografije terena gorsko-planinskoga reljefnoga područja, ali i zbog neplanske izgradnje šumskih cesta u prošlosti, koja je utjecala na njihov današnji raspored, pristupilo se i izračunu koeficijenta učinkovitosti postojeće mreže primarne šumske prometne infrastrukture. Temeljem izraza 2 koefici- jent učinkovitosti postojeće mreže primarne šumske prometne infrastrukture gospodarske jedinice Crno jezero - Marković rudine iznosi 72,91\%.

\subsection{Analiza postojeće geometrijske udaljenosti privlačenja drva - Analysis of the existing geometrical timber extraction distances}

Analiza geometrijske udaljenosti privlačenja drva provedena je $\mathrm{u}$ programskom paketu ArcGIS 10.4 pomoću alata Euclidean distance koji se zasniva na euklidskim udaljenostima od točaka pravilne mreže $(10 \times 10 \mathrm{~m})$ od sastavnica primarne šumske prometne infrastrukture. Analiza je izrađena za svaki odsjek zasebno kako bi se vizualno na grafičkom prikazu i/ili numerički u tabličnom prikazu dobio podatak o područjima (odsjecima) gospodarske jedinice Crno jezero - Marković rudine koja su nedovoljno otvorena. Temeljem analize geometrijske udaljenosti privlačenja drva dobivena je vrlo velika razlika u maksimalnim odnosno minimalnim srednjim vrijednostima za pojedini odsjek. Najveća zabilježena srednja geometrijska udaljenost privlačenja drva u iznosu od 1179,83 m zabilježena je za odsjek 68c, dok je najmanja vrijednost zabilježena za odsjek 61c u iznosu od 19,61 m.

Izračunata je i prosječna geometrijska udaljenosti privlačenja drva na razini gospodarske jedinice, koja iznosi 258,74 m, što je veća vrijednost od ciljane geometrijske udaljenosti privlačenja drva, koja prema Pravilniku za gorsko-planinsko reljefno područje iznosi $200 \mathrm{~m}$.

\subsection{Prijedlog daljnjega otvaranja - Improving forest accessibility}

Na osnovi analize postojeće primarne relativne otvorenosti istraživane gospodarske jedinice, odnosno temeljem definiranih i izlučenih neotvorenih područja, pristupilo se planiranju novih sastavnica primarnoga šumskoga transportnoga sustava. Pri tome se vodilo računa o postojećem primarnom šumskom transportnom sustavu, odabranom transportnom sustavu za pridobivanje drva, propisanim tehničkim značajkama primarnih šumskih prometnica, odabranoj srednjoj udaljenosti privlačenja drva te ostalim čimbenicima koji utječu na planiranje novih primarnih šumskih prometnica, a sve radi optimizacije primarne šumske prometne infrastrukture. Unaprijeđena mreža primarnih šumskih prometnica i unaprijeđena geometrijska udaljenost privlačenja drva u gospodarskoj jedinici Crno jezero - Marković rudine prikazane su na slici 3. 


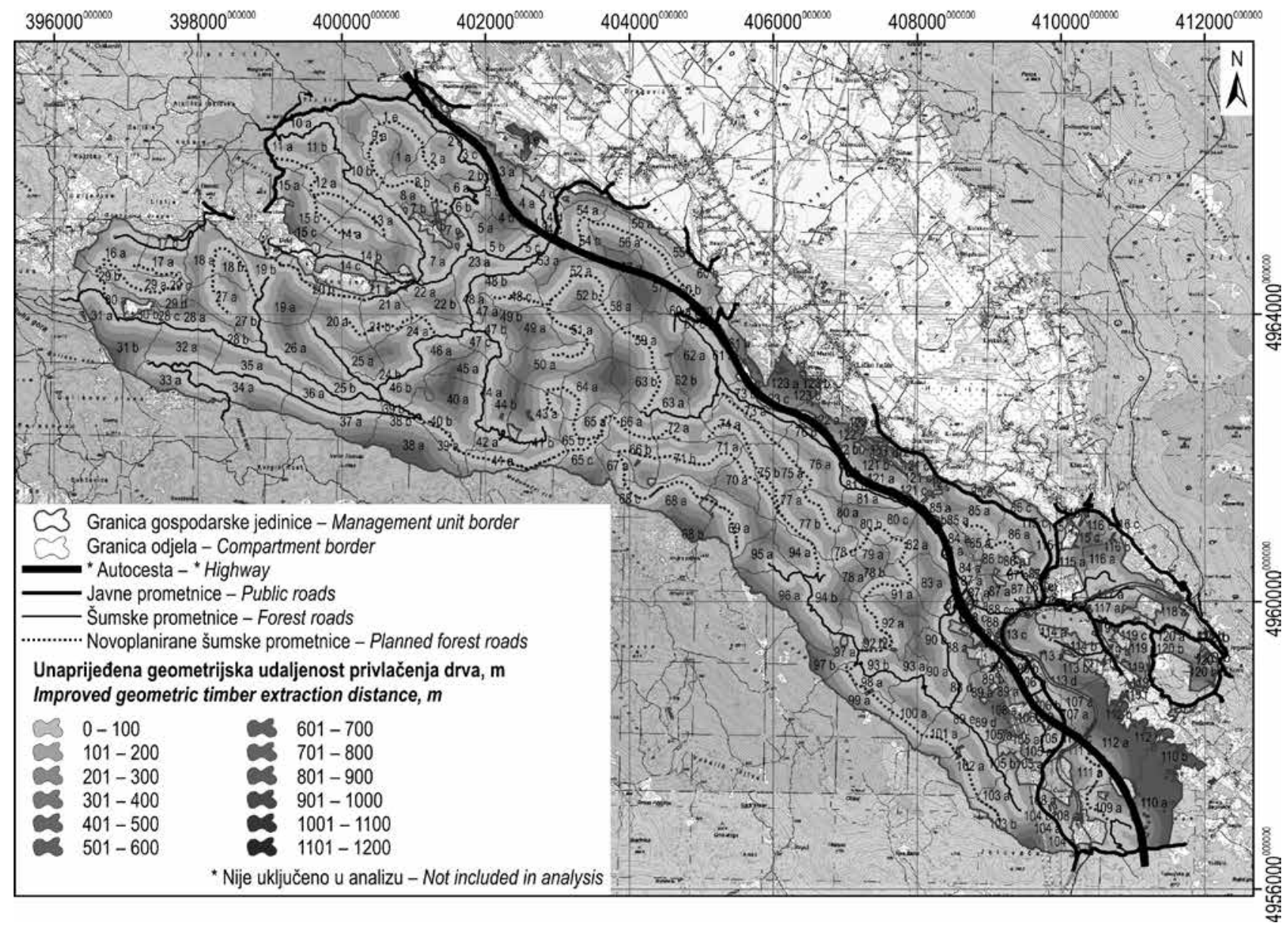

Slika 3. Unaprijeđena mreža primarne prometne infrastrukture i geometrijske udaljenosti privlačenja drva u gospodarskoj jedinici Crno jezero - Marković rudine

Fig. 3 Improved primary road infrastructure network and geometric timber extraction distance (Euclidean distance) in Management Unit Crno jezero - Marković rudine

Završni rezultat detaljnoga planiranja na slojničkim zemljovidima očitovao se u 19 novoplaniranih šumskih cesta u gospodarskoj jedinici Crno jezero Marković rudine ukupne duljine od 53,05 km.

\subsection{Raščlamba unaprijeđene mreže primarnih šumskih prometnica - Analysis of improved primary forest road network}

\subsubsection{Unaprijeđena klasična otvorenost - Improved classical forest openness}

Kako bi se došlo do podataka o unaprijeđenoj klasičnoj otvorenosti istraživane gospodarske jedinice, pristupljeno je daljnjoj analizi novoplanirane šumske prometne infrastrukture, tj. njezinih pojedinih dionica. U $100 \%$ iznosu svoje duljine u obzir su uzimane sve dionice novoplaniranih šumskih cesta koje prolaze gospodarskom jedinicom, dok su one dionice koje prolaze granicom gospodarske jedinice ili najviše do $250 \mathrm{~m}$ udaljenosti od granice s njezine vanjske ili najviše do $125 \mathrm{~m}$ udaljenosti od granice $\mathrm{s}$ njezine unutarnje strane, uzete u obračun gustoće primarne šumske prometne infrastrukture s polovicom njihove duljine (50\% duljine).

Tako je dobivena konačna duljina novoprojektiranih šumskih cesta $(48,94 \mathrm{~km})$ koje ulaze u izračun otvorenosti i koje zajedno s postojećom primarnom prometnom infrastrukturom čine unaprijeđenu klasičnu otvorenost gospodarske jedinice $u$ iznosu od $22,82 \mathrm{~km} / 1000 \mathrm{ha}$, što udovoljava i minimalno propisanoj klasičnoj otvorenosti koja prema Pravilniku za gorsko-planinsko reljefno područje iznosi 15 $\mathrm{km} / 1000$ ha odnosno $20 \mathrm{~km} / 1000$ ha (Hodić i Jurušić 2011). 


\subsubsection{Unaprijeđena relativna otvorenost - Improved primary relative accessibility}

Izračunata količina novoplaniranih šumskih cesta pridodana je postojećoj prometnoj infrastrukturi gospodarske jedinice Crno jezero - Marković rudine te je pristupljeno izračunu klasične otvorenosti na identičan način kako je opisano u poglavlju 3.1.2.

Analiza unaprijeđenoga stanja pokazivala je sljedeće:

$\Rightarrow$ ukupna površina omeđene površine iznosila je 5166,86 ha

$\Rightarrow$ jednostruko omeđena površina (zone bez preklapanja) u gospodarskoj jedinici iznosila je 2308,95 ha

$\Rightarrow$ višestruko omeđena površina (zone preklapanja više omeđenih površina) u gospodarskoj jedinici iznosila je 1742,94 ha

$\Rightarrow$ neotvorena površina gospodarske jedinice iznosila je 1293,28 ha.

Zbrajanjem jednostruko i višestruko omeđenih površina unutar gospodarske jedinice te stavljanjem $\mathrm{u}$ postotni odnos s njezinom ukupnom površinom vidljivo je da je postojeća dostupnost površine, tj. primarna relativna otvorenost koja je s postojećom mrežom primarne šumske infrastrukture iznosila $45,02 \%$ i prema sustavu procjene primarne relativne otvorenosti šuma svrstavana u kategoriju nedovoljna primarna relativna otvorenosti, unaprijeđenom mrežom povoljnija jer iznosi $75,80 \%$, što ju prema sustavu procjene primarne relativne otvorenosti šuma svrstava u kategoriju jako dobre (dostupno od 75 do $85 \%$ šumske površine).

Po završetku analize relativne otvorenosti pristupilo se izračunu koeficijenta učinkovitosti unaprijeđene mreže primarne šumske prometne infrastrukture, koji je očekivano manjih vrijednosti od koeficijenta učinkovitosti postojeće mreže šumske transportne infrastrukture iz razloga što je na istoj jedinici površine veća količina šumskih cesta, a samim time i veća koncentracija raskrižja te zona preklapanja omeđenih površina susjednih cesta. Temeljem izraza 2 koeficijent učinkovitosti unaprijeđene mreže primarne šumske prometne infrastrukture gospodarske jedinice Crno jezero - Marković rudine iznosi $64,04 \%$.

\subsection{Analiza unaprijeđenih geometrijskih udaljenosti privlačenja drva - Analysis of improved geometrical timber extraction distances}

Analiza unaprijeđenih geometrijskih udaljenosti privlačenja drva provedena je kako je opisano u poglavlju 3.2. Jedina je razlika što su postojećoj prometnoj infrastrukturi pridijeljene i novoprojektirane šumske ceste. Temeljem analize geometrijskih udaljenosti privlačenja drva smanjena je razlika u maksimalnim odnosno minimalnim srednjim vrijednostima za pojedini odsjek. Najveća zabilježena srednja geometrijska udaljenost privlačenja drva u iznosu od 763,19 m zabilježena je u odsjeku 110b, dok je najmanja vrijednost ostala ista kao i kod postojećega stanja u odsjeku 61c u iznosu od 19,61 m.

Izračunata je i prosječna geometrijska udaljenost privlačenja drva na razini gospodarske jedinice koja iznosi 258,74 m, što je veća vrijednost od ciljane geometrijske udaljenosti privlačenja drva, koja prema Pravilniku za gorsko-planinsko reljefno područje iznosi $200 \mathrm{~m}$. Ujedno je vidljivo, uspoređujući postojeću i unaprijeđenu geometrijsku udaljenost privlačenja drva u gospodarskoj jedinici Crno jezero - Marković rudine, ona smanjena ili je ostala ista u svim odsjecima gospodarske jedinice odnosno na razini gospodarske jedinice. Naime, s postojećih 258,74 m smanjena je na 140,55 m koliko iznosi za unaprijeđenu mrežu primarnih šumskih prometnica.

\section{Zaključci-Conclusions}

Provedene analize pokazale su opravdanost izrade Pravilnika za pojedino reljefno područje Republike Hrvatske koji omogućuje, uz pomoć parametara, kao što su ciljana gustoća primarne šumske prometne infrastruktre i ciljana geometrijska udaljenost privlačenja drva, odnosno pomoću sustava procjene primarne relativne otvorenosti, na jednostavan i nedvosmislen način, dolazak do informacija o kakvoći i količini mreže primarne šumske prometne infrastrukture promatranoga većega ili manjega šumskoga područja.

Nadalje, takva vrsta analize klasične i relativne otvorenosti šuma odnosno geometrijske udaljenosti privlačenja drva svrhovita je i daje korisne podatke pri taktičkom planiranju šumske transportne infrastrukture. Ona je korisna i za planiranje na razini gospodarske jedinice gdje osipanje podataka nije veliko, kao što je i prikazano na primjeru usporedbe postojeće i unaprijeđene srednje geometrijske udaljenosti privlačenja drva (slika 4).

Nakon taktičkoga planiranja šumske transportne infrastrukture na razini gospodarske jedinice i dalje ostaju dijelovi gospodarske jedinice koji su nedovoljno otvoreni (npr. odsjeci 110 b, 3 e, 112 b, 110 a, 68 b) što zbog orografije terena, što zbog neplanske izgradnje šumskih cesta u prošlosti koja je utjecala na njihov današnji raspored, a samim time i na mo- 
gućnost planiranja i prostorni raspored novih šumskih prometnica na terenu. Takvi neotvoreni dijelovi gospodarske jedinice trebali bi biti obuhvaćeni najnižom razinom planiranja $u$ šumarstvu koje se naziva lokalno odnosno operativno planiranje.

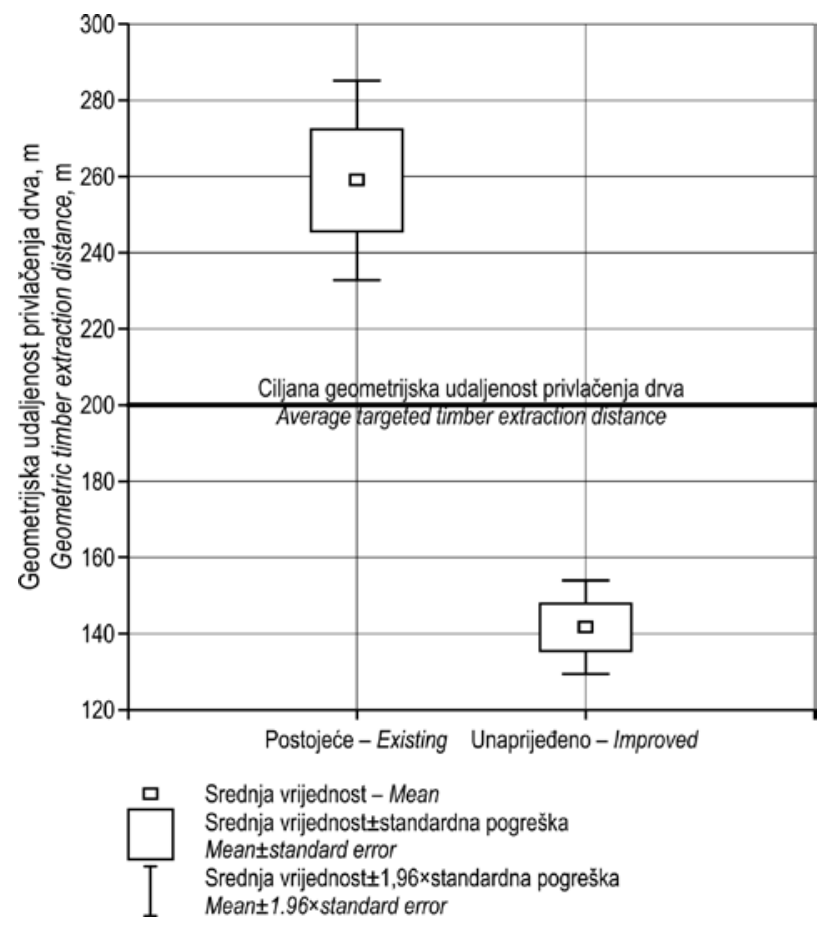

Slika 4. Usporedba postojeće i unaprijeđene srednje geometrijske udaljenosti privlačenja drva u gospodarskoj jedinici Crno jezero - Marković rudine

Fig. 4 Comparison of existing and improved average geometric timber extraction distance (Euclidean distance) in Management Unit Crno jezero - Marković rudine

Ukupna količina šumskih cesta na terenu trebala bi balansirati između dostizanja zadanih ciljeva i potreba za klasičnom i relativnom primarnom otvorenošću odnosno dostizanja ciljane geometrijske udaljenosti privlačenja, koja je u Hrvatskoj definirana Pravilnikom, te koeficijenta učinkovitosti mreže primarne šumske prometne infrastrukture.

Svakako bi u daljnjim istraživanjima valjalo analizirati koeficijente učinkovitosti pojedine sastavnice primarne šumske prometne infrastrukture i koeficijente učinkovitosti pojedine sastavnice unaprijeđene primarne šumske transportne infrastrukture te vidjeti pri kojem stupnju relativne otvorenosti oni statistički značajno padaju te može li se navedenim analizama utvrditi optimalna količina i optimalni prostorni razmještaj primarnih šumskih prometnica istraživanoga područja.

\section{Literatura - References}

Abegg, B., 1978: Die Shätzung der optimalen Dichte von Waldstraßen in traktorfahrbaren Gelände. Eidg. Anstalt für das forstiche Versuchswesen, Mitteilungen, 54, 2.

Anon., 2017: Osnova gospodarenja gospodarske jedinice Crno jezero - Marković rudine. Šumarija Otočac, UŠP Gospić.

Backmund, F., 1966: Kennzahlen für den Grand der Erschließung von Forst betrieben durch Auto fahrbare Wege. Forstwiss 85(11): 342-354.

Bosner, A., T. Poršinsky, I. Stankić, 2012: Forestry and Life Cycle Assessment. In: Global Perspectives on Sustainable Forest Management, C. A. Okia (ur.), InTech, Rijeka, 139-160.

Bumber, Z., 2011: Primjena GIS-a pri analizi otvorenosti G.J. Šiljakovačka dubrava II kroz strukturu prihoda drva u prostoru i vremenu. Magistarski rad, Šumarski fakultet Sveučilišta u Zagrebu, 139 str.

Dean, D.J., 1997: Finding optimal routes for networks of harvest site access roads using GIS-based techniques. Canadian Journal of Forest Resources 27(1): 11-22. https:// doi.org/10.1139/x96-144

Dietz, P., W. Knigge, H. Loffler, 1984: Walderschliessung (Forest Roads). Verlag Paul Parey, Hamburg - Berlin, 426 str.

Enache, A., 2009: Elaboration of a Forest Road Network in Trauch Forest District, Wittgenstein Forest Administration, Hohenberg, Austria. Master Thesis, University of Natural Resources and Life Sciences - BOKU, Vienna, 67 str.

Hodić, I., Z. Jurušić, 2011: Analiza primarne otvorenosti šuma kojima gospodare HŠ d.o.o. Zagreb kao podloga za kreiranje buduće politike izgradnje šumskih cesta. Šumarski list 135(9-10): 487-499.

Jeličić, V., 1983: Šumske ceste i putevi. Samoupravna interesna zajednica odgoja i usmjerenog obrazovanja šumarstva i drvne industrije, Zagreb, 193 str.

Jeličić, V., 1988: Otvaranje šuma i savremeni transport drveta. Dokumentacija za tehniku i tehnologiju u šumarstvu, Jugoslovenski poljoprivredno-šumarski centar, Beograd, 63 str.

Krpan, A.P.B., 1992: Iskorišćivanje šuma. U: Đ. Rauš (ur.), Šume u Hrvatskoj, Šumarski fakultet Sveučilišta u Zagrebu i Hrvatske šume j.p., Zagreb, 153-170.

Murray, T.A., 1998: Rout Planning for Harvest Site Access. Canadian Journal of Forest Research 28(7): 1084-1087. https://doi.org/10.1139/x98-122

Pearce, J.K. 1974: Forest Engineering Handbook, a Guide for Logging Planning and Forest Road Engineering, Bureau of Land Management. Oregon State Office, US Department of the Interior. Divisions 100-800, 220 str.

Pentek, T., 2002: Računalni modeli optimizacije mreže šumskih cesta s obzirom na dominantne utjecajne čimbe- 
nike. Disertacija, Šumarski fakultet Sveučilišta u Zagrebu, 271 str.

Pentek, T., D. Pičman, H. Nevečerel, 2005: Planiranje šumskih prometnica - postojeća situacija, determiniranje problema i smjernice budućeg djelovanja. Nova mehanizacija šumarstva 26(1): 55-63.

Pentek, T., 2012: Šumske prometnice. Skripta, Šumarski fakultet Sveučilišta u Zagrebu, 373 str.

Pentek, T., H. Nevečerel, T. Ecimović, K. Lepoglavec, I. Papa, Ž. Tomašić, 2014: Strategijsko planiranje šumskih prometnica u Republici Hrvatskoj - raščlamba postojećega stanja kao podloga za buduće aktivnosti. Nova mehanizacija šumarstva 35 (1): 63-78.

Pentek, T., A. Đuka, I. Papa, D. Damić, T. Poršinsky, T. 2016: Elaborat učinkovitosti primarne šumske prometne infrastrukture - alternativa studiji primarnog otvaranja šuma ili samo prijelazno rješenje? Šumarski list 140(9-10): 435-452. https://doi.org/10.31298/sl.140.9-10.1

Potočnik, I., 1996: Mnogonamenska raba gozdnih cest kot kriterij za njihovo kategorizacijo. Disertacija, Biotehniška fakulteta Univerze v Ljubljani, 241 str.

Segebaden, G. von, 1964: Studies of cross-country transport distances and road net extension. Studia Forestalia Suecica 18: 67 str.
Sever, S., 1992: Šumarski strojevi. Tehnička enciklopedija XII, Leksikografski zavod Miroslav Krleža, Zagreb, 519-531 str.

Šikić, D., B. Babić, D. Topolnik, I. Knežević, D. Božičević, Ž. Švabe, I. Piria, S. Sever, 1989: Tehnički uvjeti za gospodarske ceste. Znanstveni savjet za promet Jugoslavenske akademije znanosti i umjetnosti, Zagreb, 78 str.

Stampfer, K., 2010: Forest Engineering - Course Script. Institute of Forest Engineering, Department of Forest and Soil Sciences, University of Natural Resources and Life Sciences - BOKU, Vienna, Austria.

Tehrani, F.B., B. Majnounian, E. Abdi, G. Z. Amiri, 2015: Impacts of Forest Road on Plant Species Diversity in a Hyrcanian Forest, Iran. Croatian Journal of Forest Engineering 36(1): 63-71.

* Pravilnik o provedbi mjere M04 »Ulaganja u fizičku imovinu«, podmjere 4.3. »Potpora za ulaganja u infrastrukturu vezano uz razvoj, modernizaciju i prilagodbu poljoprivrede i šumarstva«, tipa operacije 4.3.3. »Ulaganje $\mathrm{u}$ šumsku infrastrukturu« iz Programa ruralnog razvoja Republike Hrvatske za razdoblje 2014. - 2020. NN 106/15, 65/17, 77/17.

* Smjernice za izradu Elaborata radilišta za radove u šumarstvu. Hrvatska komora inženjera šumarstva i drvne tehnologije. NN 16/15.

\section{Abstract}

\section{Case Study of Primary Forest Accessibility for Management Unit Crno jezero - Marković rudine Forestry Office Otočac}

Well planned forest traffic infrastructure, which is optimally integrated into the forest ecosystem, represents one of the basic prerequisites for the rational management of the forest ecosystem. The total amount of forest roads, their location and their specified technical characteristics must be sufficient for the best possible forest management. If the forest traffic infrastructure is properly distributed in the area, it enables all the tasks covered by forest management plans, with minimal costs for their construction and maintenance. This paper presents the current state of primary accessibility of the Management Unit Crno jezero - Marković rudine and gives guidelines to achieve very good primary relative accessibility. The processing of field data was performed with the ArcGIS 10.4 and QGIS 2.18.20 computer programs. It has been established that the classical forest openness in the studied Management Unit was $13.66 \mathrm{~km} / 1000 \mathrm{ha}$, which does not even meet the minimum specified classical openness, this being $15 \mathrm{~km} / 1000$ ha for mountainous/hilly areas. When analysing the results of primary relative openness, a very similar situation was found as in the case of classical openness; the primary relative openness was $45.05 \%$, which is insufficient. Furthermore, the existing mean geometric distances of timber extraction were analysed separately for each compartment and for the entire managemnt unit, which was 258.74 $m$. A careful planning resulted in the design of a total of $53.05 \mathrm{~km}$ of new forest roads, which ultimately resulted in an increase in the classical forest openness amounting to $22.82 \mathrm{~km} / 1000$ ha and an increase in the primary relative openness amounting to $75.8 \%$, while the mean geometric distance of timber extraction was reduced to $140.55 \mathrm{~m}$.

Keywords: forest roads, relative forest openness, geometric distances of timber extraction, ArcGIS 
Adrese autorâ - Authors' addreses:

Doc. dr. sc. Ivica Papa

e-pošta: ipapa@sumfak.hr

Prof. dr. sc. Tibor Pentek

e-pošta: tpentek@sumfak.hr

David Janeš, mag. ing. silv. *

e-pošta: djanes@sumfak.hr

Doc. dr. sc. Andreja Đuka

e-pošta: aduka@sumfak.hr

Šumarski fakultet Sveučilišta u Zagrebu

Zavod za šumarske tehnike i tehnologije

Svetošimunska 25

10000 Zagreb

HRVATSKA

Enio Valinčić, mag. ing. silv.

e-pošta: eniovalincic@gmail.com

Sinac 357A

53220 Otočac

Primljeno (Received): 1. 11. 2019.

HRVATSKA

Prihvaćeno (Accepted): 3. 12. 2019.

* Glavni autor - Corresponding author 